\title{
The Lean Enterprise at the Design Office
}

\author{
Dawlat Elmosalmi \\ Dawlatmossalamy@hotmail.com \\ Engineering Consultants Group, Doha, Qatar \\ Mohamed Mohsen Ibrahim \\ mohamedmohsenae@gmail.com \\ Engineering Consultants Group, Doha, Qatar
}

\begin{abstract}
This paper presents the lean practice implementation, which led to a transformation in the design offices/projects explaining how implementing lean principles is affecting the projects at the design phase and also affecting the whole system at the design firm. The paper is divided into two parts; theoretical and practical. The theoretical part will explain lean concept definition, values and wastes, wastes solutions, lean principles and levels of lean implementation. The practical part will present a case study for a successful lean transformation in a consultancy firm showing the challenges faced and the steps for a successful implementation on office activities and on projects as well based on a company's experience and observations reducing wastes and adding value to the work process within the organization to achieve the three parts goal of better, cheaper and faster projects. This research will be enriched by the audiences' interaction, sharing different experiences in lean transformation for maximum benefits.
\end{abstract}

Keywords: Lean thinking; Culture; BIM; Value; Waste; Design phase; Office activities

\section{INTRODUCTION}

The Architecture, Engineering, Construction and Operation (AECO) industry is always concerned with improving efficiency, quality and profitability. New innovative processes, such as the lean practice, can give solutions to the trilogy of problems in the AECO industry: time, cost and quality. The integration of the four key functions: process, technology, organization, and information management are required for any enterprise (Arleroth \& Kristensson, 2011).

This paper aims to define clearly the concepts of lean thinking, its goals, benefits and challenges faced when first implemented and how to implement it successfully in a consultancy firm by presenting a case study and explaining how lean can be integrated with Building Information Modelling (BIM) achieving less waste and adding value to projects reaching client satisfaction.

\section{LEAN CONCEPT}

Lean is simplicity in its most valuable form. It has many definitions addressing efficiency, improvement, adding value and eliminating wastes (Womack \& Jones, 2005).

\subsection{Lean Definitions and History}

Lean is the elimination of waste from the production cycle. Value is added at any work 
process when waste is removed from the supply chain, leading to lower costs, shorter time schedule and higher profits. Being "lean" is achieved by delivering the right things (including information) to the right location or place in the right amount, at the right time and under the right conditions. Value can be defined as what the customer needs at the end of the process. While waste can be defined as any process or action which takes place in the process but does not add value. Lean as a term was first signified in the manufacturing industry by James P. Womack in his book "Lean Thinking" and the book, "The Machine That Changed the World". It is based on an industrial concept created by the Japanese during the 1900s. The founder of lean production was Toyota in its Production System (TPS). Womack's definition of lean production in 1990 was that it is a method which combines the advantages of craft production and mass production. The manufacturing industry has applied lean thinking successfully; the same principles were applied by lean professionals to the construction industry as a response to address the traditional model shortcomings. It is a fact that there is approximately 30 percent waste in our processes and delivery methods. Also, it is known that manufacturing benefits from repetition, fixed program, controlled environment and known conditions while construction suffers from prototypes at scale 1:1, constant changes, unforeseen costs and increased risks (Badurdeen, 2007) (Arleroth \& Kristensson, 2011) (Elmosalmi 2014).

\subsection{Wastes classification and solutions}

According to lean thinking, there are eight types of wastes, which are connected to each other and interrelated: (1) Overproduction waste is the making or producing more than is needed-leading to excess stocks or fabricating material or ordering it too soon. (2) Waiting time waste is people or equipment waiting for a production process to be completed or resources to arrive. The operator is slower than the production line. (3) Transport waste is moving resources (people/ materials) unnecessarily (ex: lost data because of unorganized data folders, or working space not designed efficiently). (4) Motion waste is a worker who appears to be busy but actually not adding any value. (5) Stocks waste is the material or information stored at office, site or yard, work in progress (processing work), unused tools and data (often held as an acceptable buffer but should not be excessive). (6) Defects (errors) waste is the rework or output that does not reach the required quality standard. (7) Over processing waste is the unnecessary reporting, non-value-added activities or actions, non-value-added reviews. (8) Unused employee creativity waste is wasting time, wasting human resources skills, losing better innovative solutions by not engaging the right persons at the right tasks or outsourcing some tasks because of not knowing the employee's capabilities and skills. There are five waste solutions which are sort, set in order, shine, standardize and sustain. Sort is by separating the tools into two groups: using and not using. Set in order is the items in the "using" group that were set in order. Shine is keeping the area clean and everything in its location. Standardize is to apply the standards to the work area. Sustain is maintaining the gain (Bottirov, 2011).

\subsection{Lean thinking principles}

Lean thinking principles focus on improving efficiency and productivity by better coordination of information and maintaining better flows. The five lean thinking 
principles are, identify customer value, identify the value stream, implement flow, implement pull, and seek perfection. (1) Identify customer value principle is concerned with client identification and understanding about what the client expectations are and what he is willing to pay for. (2) Identify the value stream is both value added, and nonvalue-added actions required to bring a product through the main flows. (3) Implement flow is to continually deliver the product from start to finish. Synchronize and align so there is only minimum waiting time for work and workers. (4) Implement pull: it means producing only what customer needs at the end of the process or to start new work only when there is a customer demand for it. It results from the fundamental concept of Just in Time (JIT), which states that production should be triggered based on actual demand from customers. (5) Seek perfection (constant pursuit of improvement) is the kaizen concept (the Japanese term for continuous improvement, through a Plan-Do-CheckAct (PDCA) cycle). In lean systems, transparency is required as a main concept, where everyone can see everything, and systems are able to communicate with people, e.g., use of indicators and standards, where immediate recognition of deviations is allowed all the time (Womack \& Jones, 1996) (Elmosalmi 2014).

\subsection{Lean production methods}

There are several lean production methods such as the Lean Operating System (LOS), Cell Production and Kaizen. LOS concept is to create reliability and producing consistent results in the day-to-day operations and in the delivery of projects (monitoring and following up work daily with the team) so that value can be added, and wastes are eliminated. In cell production workers are organized into several teams. Each team is responsible for a particular part of the production process. Each cell is made up of many teams who deliver finished items on to the next cell in the production process. In traditional production, products were manufactured in separate areas as a production line. Cell production can lead to efficient improvements due to increased motivation (team spirit and added responsibility given to cells) and workers sharing their skills and expertise. The Kaizen concept is focusing on engaging employees/stakeholders in developing systems and improving work processes in parallel with their ongoing tasks which helps in improving performance. It also seeks to standardize processes and eliminate or reduce waste (Forbes \& Ahmed, 2011) (Elmosalmi 2014).

\section{LEAN IMPLEMENTATION}

Several requirements are needed at any organization for successful lean implementation; the organization top management and employees should be willing to change, they should have commitment to training and able to learn, they should have a mindset which is quality oriented, they must have commitment to reducing or eliminating waste, commitment to cost and performance measures, willingness to implement lean during the design stages. Also, the organization must enhance the collaborative relationships and its information technology systems. Lean thinking can be applied on many levels as shown in the Figure 1. 


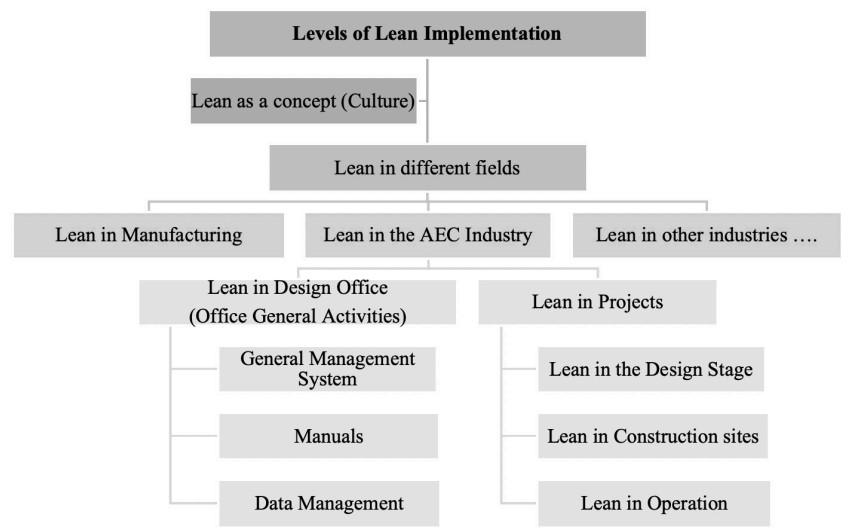

Figure 1: Levels of lean implementation

\section{CASE STUDY FOR LEAN IMPLEMENTATION AT THE DESIGN OFFICE}

ECG (Engineering Consultants Group) company which has been successfully implementing the lean practice for the past few years in both Egypt and Qatar offices is chosen as a case study to show how lean practice can be implemented in the design office on both levels; the office activities and the projects. Lean can be implemented with a very wide range of benefits at the design office, whether it is a consultancy firm or a design firm. The office activities include but not limit themselves to the company general system of work, the manuals and standards of the company, the administrative processes, the human resources management systems and the data management system.

\subsection{Lean drivers (problem identification)}

The huge amount of wastes (materialistic and non-materialistic) which the teams were suffering from were the main driver for the lean transformation. In addition, the company's main goal was achieving its clients' satisfaction through better, faster, cheaper delivery of projects while maintaining its employees' satisfaction, development and improvement, and that could not have been achieved successfully without implementing new innovative practices as the lean practice. Examples of the wastes discussed and eliminated after implementing lean practice at office activities are projects waiting for human resources, waiting for software installation, movement as a result of layout of working area, unused data, information, standards, layers, families, reports, and outsourcing in some tasks increasing projects costs and over processing in data transfer between different offices around the world.

\subsection{Sources of wastes in the office}

The sources of wastes can be classified into people waste, process waste, information waste and asset waste. People wastes are the wastes that happen because of bad human resources; bad leaders and due to lack of training. Process wastes are wastes taking place because of work duplication, improper planning, lacking monitoring and supervision. Information wastes are lost data and material important for accomplishing the work or bad processing of communication data and information. Asset waste is the improper utilization of material and property resources and includes wastes related to excess 
inventory, work in process, areas and facilities not properly used. The first step towards lean enterprise is to be fully aware of the wastes existing in the organization. Some of the wastes can be hidden inside long processes so it is necessary to make the entire value stream related to office activities visible by creating the Value Stream Map (VSM) so everyone can discuss the wastes clearly with transparency so that wastes can be easily eliminated (Lareau, 2003).

\subsection{Challenges faced}

The main challenge was changing the mindset of employees from being production oriented to targeting "continuous improvement" by starting with the right people and involving them in the lean transformation. Examples of the challenges are changing employees' working culture, lack of cooperation from some employees, lack of long-term forecast and investment, fear of admitting the wastes existence, long implementation time and lack of lean knowledge.

\subsection{Lean Implementation plan}

To transform the organization to a lean one, three main phases took place. First was formulating the idea by discussing it with the top management and learning about lean, then taking the decision by the top management, identifying missions and visions (creating a future vision for development by each department), choosing lean champions, identifying metrics, and giving lean awareness sessions. The second phase is the implementation phase, done by evaluating the organization. It is done by writing Waste Analysis Reports (WAR) for departments (Figure 2), and involves suggesting solutions by the nominated lean candidates, identifying responsibilities (that who is responsible for waste elimination), identifying priorities and capabilities by prioritizing the wastes elimination solutions and put them in order according to capabilities and urgency. Moreover, creating a time line for wastes elimination, implementing lean principles in both office activities and new projects, and wastes elimination. The third phase is evaluation and development by auditing and evaluating, continuing development of teams (targeting more lean certifications), following up to confirm lean commitment.

Table 1: Partial sample of the Waste Analysis Report (WAR)

\begin{tabular}{|c|c|c|c|c|c|c|c|}
\hline Wastes & Type & Waste description & Responsibility & $\begin{array}{l}\text { Weight } \\
\text { (1 to 10) }\end{array}$ & $\begin{array}{c}\text { Phase of } \\
\text { Implementation }\end{array}$ & Solution & $\begin{array}{c}\text { Cost of } \\
\text { Elimination }\end{array}$ \\
\hline \multirow{7}{*}{ Overproduction } & \multirow{7}{*}{ Technical } & Overproduction as a result of: & & & & & \\
\hline & & -Extra Level of Detail (LOD) & $\begin{array}{c}\text { CAD/BIM } \\
\text { Management+ } \\
\text { Project } \\
\text { Management }\end{array}$ & 9 & 1 & $\begin{array}{l}\text {-Work according to } \\
\text { required LOD }\end{array}$ & $x$ \\
\hline & & $\begin{array}{l}\text { - Overproduction as a result of } \\
\text { unclear scope of work }\end{array}$ & Arc+Management & 6 & 2 & $\begin{array}{l}\text { - Committing to the scope } \\
\text { (by conducting Team } \\
\text { Leaders and project } \\
\text { managers awareness } \\
\text { sessions) }\end{array}$ & $x$ \\
\hline & & $\begin{array}{l}\text { - Extra unnecessary data in } \\
\text { sheets or information } \\
\text { duplication (Ex. Extra } \\
\text { dimensions) }\end{array}$ & Arc & 8 & 1 & $\begin{array}{l}\text {-Refer to Manuals and } \\
\text { Standards (and preparing } \\
\text { sessions to architects and } \\
\text { monitor their commitment } \\
\text { to what they have learnt) }\end{array}$ & $x$ \\
\hline & & -Delivery methods in BIM & $\begin{array}{l}\text { Arc+BIM } \\
\text { Management }\end{array}$ & 4 & 3 & $\begin{array}{l}\text { - Managing project phases } \\
\text { according to process used }\end{array}$ & $x$ \\
\hline & & -Incoordination & Arc & 7 & 1 & $\begin{array}{l}\text { Prototyping in large scale } \\
\text { projects should be settled } \\
\text { from the beginning of the } \\
\text { project. }\end{array}$ & $x$ \\
\hline & & $\begin{array}{l}\text { - Unnecessary submissions } \\
\text { (progress print) or Unscheduled } \\
\text { submissions }\end{array}$ & Management & 8 & 1 & & $x$ \\
\hline
\end{tabular}




\section{CASE STUDY FOR LEAN IMPLEMENTATION ON PROJECTS}

Lean thinking can be implemented on all projects at the design stage, the construction stage and at the operation stage. The project selected by ECG to be a case study was a transit-oriented development complex in Doha. It was Detailed Design Scope integrating BIM and lean practices.

\subsection{Challenges faced by the project team}

The challenges faced by the team of that mega project were design challenges, technology challenges, social and cultural challenges, process implementation, coordination and collaboration, simulation, man-hours budget and resource assignment, waste elimination, resources optimization, quality control and the complex and huge amount of data in assets management life-cycle.

Since all project information is managed by BIM, numerous numbers of BIM models have been produced across different locations accompanied by huge amount of information for different purposes. This information can be classified and sorted with reference to the project stage, phase and use. During the project lifecycle many information exchange issues, related to quality and interoperability may appear. Manual monitoring, reviewing and analyzing of this amount of information became more sophisticated; completeness and accuracy became the major issue of handing over models for each BIM use (Ningappa, 2011).

\subsection{Lean implementation plan on the project}

The project team used technologies that facilitate lean design through an automated solution, facilitate the aggregation, extraction of important information, reviewing the correctness and completeness of information and helps with decision making on different management levels. The automation process can be classified into four phases: Aggregation, extraction, reviewing \& analyzing, and optimization for better decision making. This leads to reduce the duplicative efforts of traditional drafting and traditional coordination methods. BIM allowed the design team to focus more on high-value design earlier through analysis and visualization and deliver the best value to the customer. The applications of BIM helped reduce several kinds of waste. For example, visualization helped reduce confusion, which leads to less error and effectively, leads to less rework. Therefore, less waste due to correction, rework and defects. The tools and techniques used in integrating BIM with lean practice are implementing Common Data Environment (CDE) for design management across different design offices (Figure 3), efficient design coordination, early clash detection for less site wastes in terms of (time, resources \& materials), monitoring design productivity, processes and resources efficiently (Figure 4), accurate and automated material take off and cost estimation through the BIM Model, proper phasing and construction planning using 4D simulations, apply production control: utilize a small design batch approach, evaluating against project requirements purpose.

\subsection{Detailed sample for technological lean application: Phases of implementation for information management}

Aggregation of BIM information: Electronic data management solution and common 
data environment implementation should be obligatory; this facilitates managing and controlling the data of all assets. There is now a diversity of EDMS (Electronic Data Management System) \& CDEs software, which provide divergent solutions relevant to each project requirements. ECG has managed different projects information utilizing PEER software which is controlled by internally developed electronic data management software complying with ISO BIM requirements, guidelines and project's needs. The elements of the integrated systems are: Data servers, models server, PEER software, and ECG electronic data management system. (Figure 2 illustrates a general workflow for the integrated system).

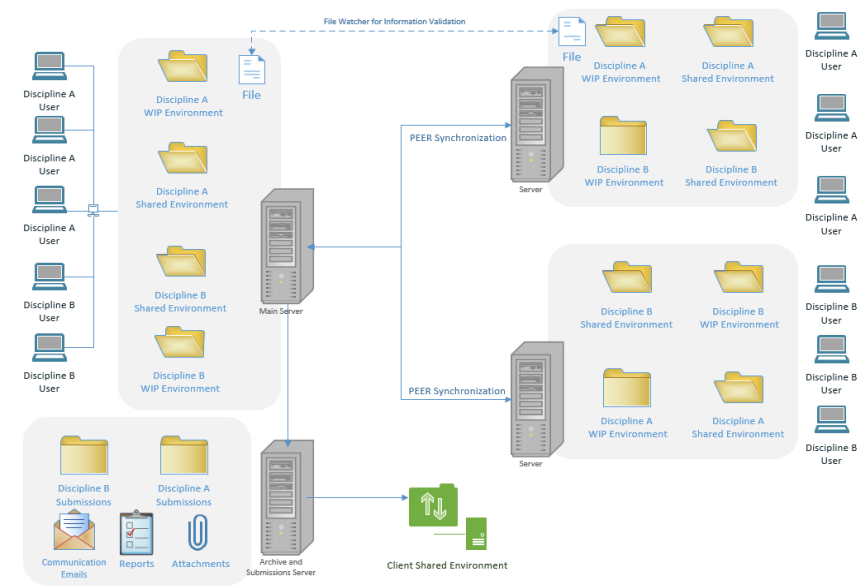

Figure 2: General workflow for the integrated system

Data aggregation from BIM models for check and verification: ECG has elaborated a software for BIM validation and data aggregation using programming codes and Revit API where data can be driven by an automatic process from linked models per request or based on a time interval, this varies based on project and workflow needs.

Instantaneous accessibility of aggregated information for record, check and analyze: The aggregated information earlier demonstrated is saved on the allocated server. The responsibility of processing the received requests from a front-end application falls on a backend server hosted online, which performs as an example the following tasks: insert new project or do modification for the existing one, add/delete users, and get information of diagrams and schedules, etc. Frontend application is responsible to visualize the information in the shape of readable diagrams and schedules with filtering and sorting features (Figure 3). 


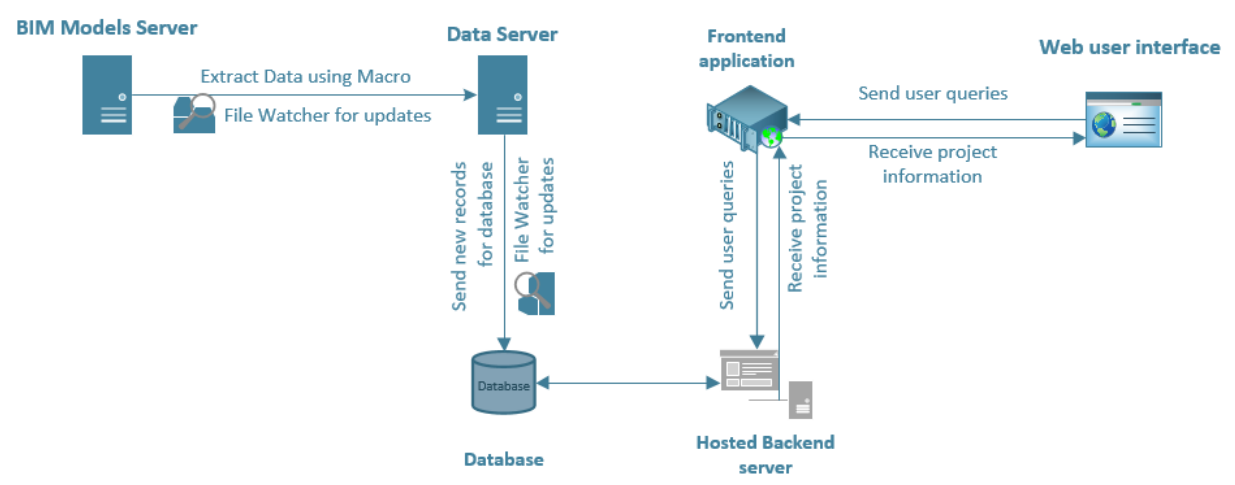

Figure 3: Illustration for the information aggregation and exchange

Design workflows and procedures optimization with reference to aggregated information: The optimization of design workflows and procedures can be achieved if aggregated information is monitored and analyzed for enhanced decision-making and gaining \& documenting experience from projects. Sample case, the complexity of architectural BIM models increased suddenly which was a reason for lower production efficiency. When the collected information is analyzed for investigating the reason for that, the following outcomes were noted regarding BIM models' items for number of model categories at each shared version of the model: Count of model elements increased from 72,000 elements (10 months progress) to 208,000 elements (one-year design production duration). This means an increase of 136 thousand elements in 2-months of progress (Figure 4).

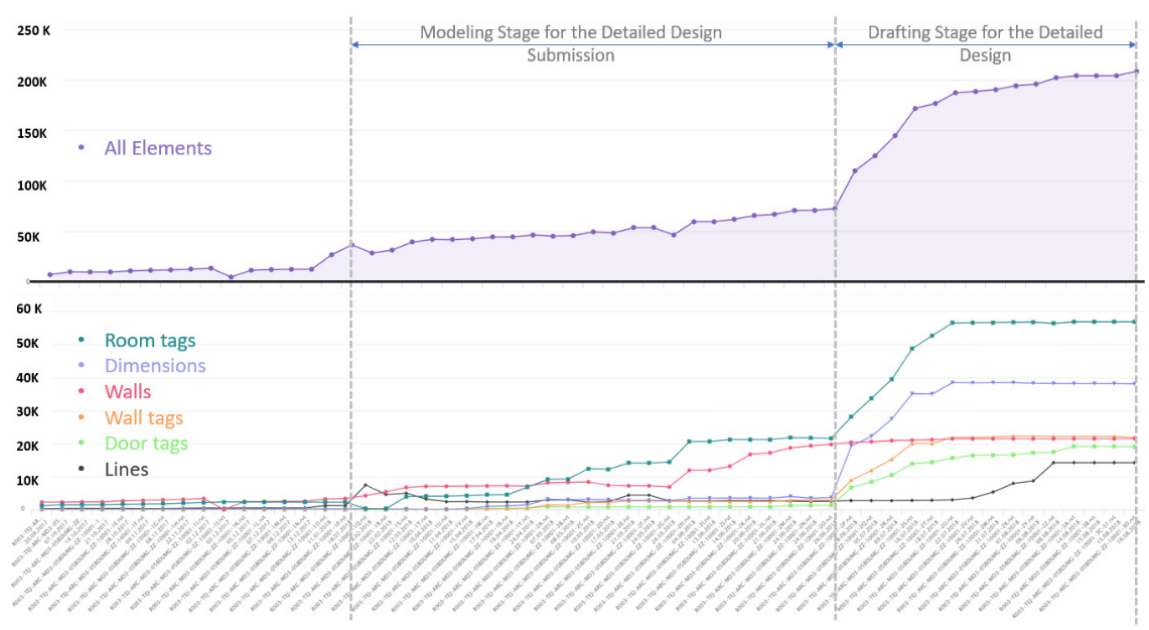

Figure 4: BIM production progress (modelling and drafting) across a year

By analyzing the last arch. model, more than $76 \%$ of the model content was related to 7 element types out of 69 used type as in Figure 5. 


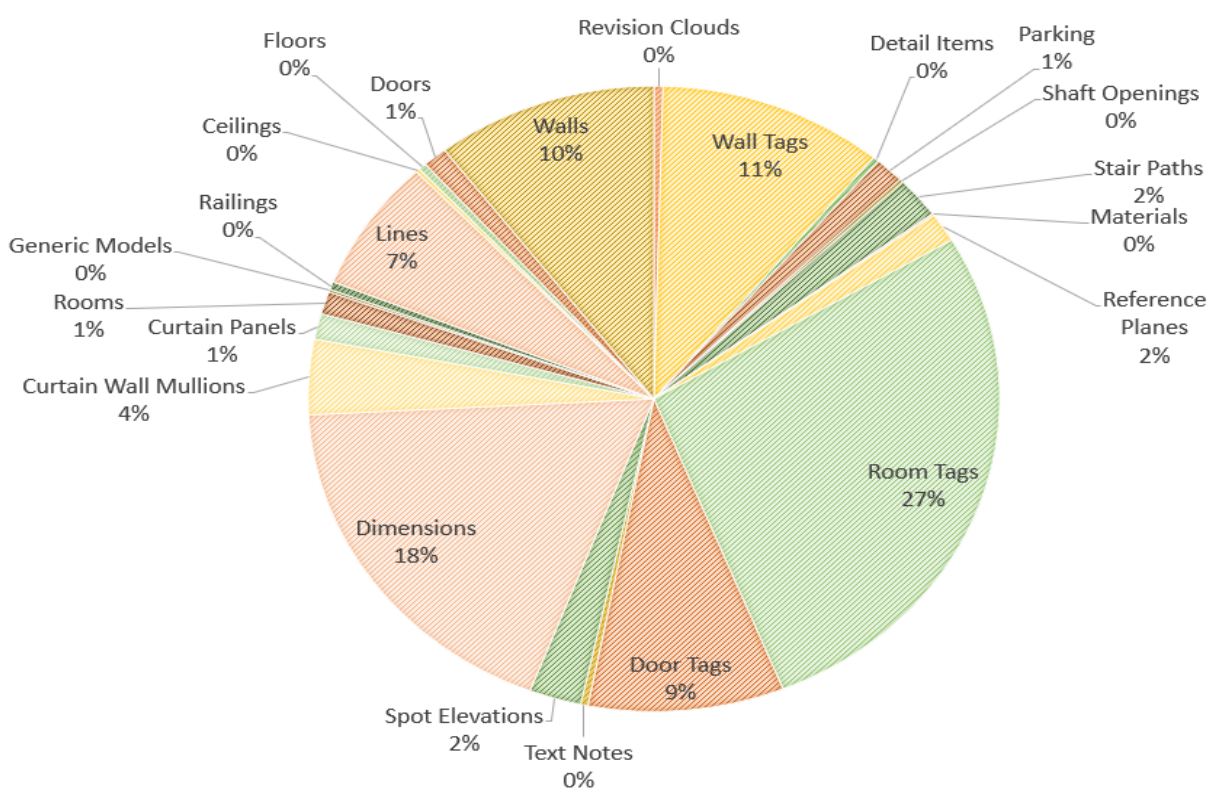

Figure 5: Model content ratios at the latest shared version of the architectural model

One of the most crucial issues for BIM efficient production is to have duplicated model elements. Architectural scope of production was split into two different models managed by two teams (architects \& interior designers). When progress was analyzed, a justification was found for design conflicts issues. One of the most critical issues found was ceiling production. A duplication of ceiling elements existed for a duration of 27 days at both models which caused coordination conflicts related to hosting of ceiling elements (spot lights, air terminals, smoke sensors \& detectors, and others) on ARC ceiling elements and which was deleted at a developed phase of design production (Figure 6) (Mohsen et al., 2019).

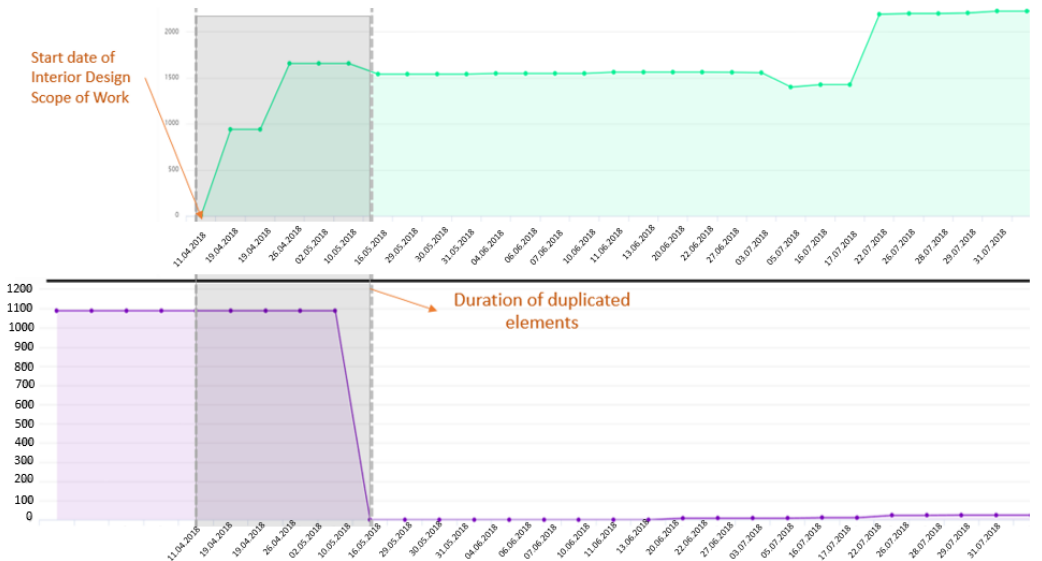

Figure 6: Analysis of the duration of existence of duplicated ceiling elements 


\section{CONCLUSION}

Lean is a way of thinking which can be applied at the design office as well as in construction sites. Being lean is more than just a set of tools and requires a cultural shift among the participating parties - the team must be constantly looking for ways to collaborate and incorporate continuous improvement into the project and in the company as a whole. Applying the lean practice in firms through managing the office activities with lean thinking principles helped in reducing wastes and unnecessary non-value adding activities which costs the company money and act as obstacles in the way of the company's continuous improvement. Also, from practitioners' experience, it was found that to sustain lean operations, the human resources function must support them, beginning with hiring people who are innovative, initiative and can work in a lean working culture.

Managing the projects using lean principles in integration with BIM processes helped in reducing wastes, increasing output value through systematic consideration on customer requirements (by reducing variability, reducing cycle time), simplifying by minimizing the number of steps, increasing output flexibility, increasing process transparency, focusing control on the complete process, building continuous improvement into the process, achieving flow at the value stream. Project quality level has improved significantly when BIM was used as a tool to support implementation of lean thinking on AECO projects. Coordination between different disciplines of the project could be one of the project quality indicators.

The integration of lean practices with BIM in an integrated methodology is inherently the best process for AECO firms to achieve continuous improvement and achieve faster, better and cheaper projects.

\section{REFERENCES}

Arleroth, J. \& Kristensson, H. A. (2011). Waste in Lean Construction (M.Sc., Thesis, Department of technology management and economics). Chalmers University of technology, Gothenburg, Sweden.

Badurdeen, A. (2007). Lean Manufacturing Basics (an online book). Retrieved from http://www. leanmanufacturingconcepts.com.

Bottirov, O. (2011). Lean construction in construction company (Phd, Viauc University, Department of construction management). Denmark.

Elmosalmi, D. (2014). Building Information Modeling (BIM) Technology Implementation in Lean Architecture through Managing Human Resource (M.Sc., Thesis, Department of Architecture). Ain Shams University, Egypt.

Lareau, W. (2003). Office Kaizen - Transforming Office Operations into a Strategic Competitive Advantage. Milwaukee: American Society for Quality.

Mohsen, M. \& others (2019). Necessity of Monitoring Vital Bim Information for Optimized Design Process Management. Witpress, Ltd.

Forbes, Lincoln H. \& Ahmed, Syed M. (2011). Modern Construction: Lean Project Delivery and Integrated Practices. CRC press, Taylor and Francis Group, LLC.

Ningappa, G. (2011). Use of Lean and Building Information Modeling (BIM) in the Construction 
Process; Does BIM make it Leaner?' (M.Sc., Georgia Institute of Technology).

Womack, James P. \& Daniel T. Jones (1996). Lean Thinking: Banish Waste and Create Wealth in Your Corporation. New York: Simon and Schuter.

Womack, James P. \& Daniel T. Jones (2005). Lean Solutions: How Companies and Customers Can Create Value and Wealth Together. Simon and Schuster, New York, NY. 